\title{
Peertechz
}
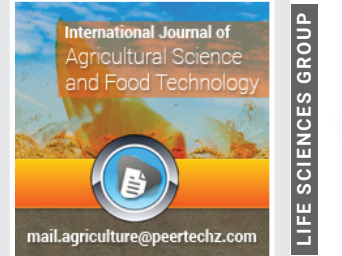

每

\section{The effect of Zinc chelate and}

\section{Potassium sulfate topdressing} on alleviating the Cadmium (Cd) and Nitrate ( $\left.\mathrm{NO}_{3}-\right)$

\section{toxicity in potato tubers of Ardabil province, Iran}

\section{Seyyede Khamsa Asbaghian Namini*, Mohammad Jafar Malakouti ${ }^{1}$ and Akbar Ghavidel ${ }^{2}$}

${ }^{1}$ Department of Soil Science, Faculty of Agriculture, Tarbiat Modares University, Tehran, Iran

${ }^{2}$ Department of Soil Science, Faculty of Agriculture and Natural resources, University of Mohaghegh Ardabili, Ardabil, Iran

Received: 15 December, 2020

Accepted: 22 January, 2021

Published: 27 January, 2021

*Corresponding author: Seyyede Khamsa Asbaghian Namini, Department of Soil Science, Faculty of Agriculture, Tarbiat Modares University, Tehran, Iran, E-mail:Khamsa.Asbaghian@Modares.ac.ir

Keywords: Potato (Solanum tuberosum L.); Cadmium $(\mathrm{Cd})$; Nitrate $\left(\mathrm{NO}_{3}{ }^{-}\right)$; Imbalanced fertilization; $\mathrm{Zn}$ fertilizers; Healthy products

https://www.peertechz.com

Check for updates

\begin{abstract}
Contamination of tuberous vegetables such as potato (Solanum tuberosum L.) with Cadmium (Cd) and Nitrate ( $\mathrm{NO}_{3}^{-}$) due to the imbalanced fertilization may pose health risks to consumers. Potato is one of the dominant agricultural vegetables in Iran which is consumed in different ways. Excessive amounts of $\mathrm{Cd}^{-}$and $\mathrm{NO}_{3}{ }^{-i n}$ potatoes can lead to organ dysfunction and various diseases. The aim of this study was to investigate the role of $\mathrm{Zn}$-fertilizers on increasing yield and reducing the $\mathrm{Cd}$ concentration and also monitoring the $\mathrm{NO}_{3}$ - content in potato tubers of Ardabil province. For this purpose, In the first phase, potato tubers were sampled from 10 most important markets in the form of imbalanced completely randomized design in 2019 and the concentration of Cd when consumed with and without potato peel was assessed, then, in the second phase, the effect of $\mathrm{Zn}$-fertilizers on the yield and concentration of $\mathrm{Cd}$ in high-risk areas was investigated in 2020 growing season. The results indicated that the maximum concentration of $\mathrm{Cd}$ among the samples was $0.14 \mathrm{mg} \mathrm{kg}^{-1}$ fresh weight and the minimum was $0.02 \mathrm{mg} \mathrm{kg}^{-1}$ fresh weight. According to the results, there was no significant difference between potato samples analyzed with peel and without peel. Therefore, in the second phase, in order to investigate the effect of Zn-fertilizers topdressing on potato tubers yield and Cd concentration, an experiment was conducted in randomized complete block design with 3 treatments and 3 replications in Ardabil University's farm. Experimental treatments were the T1 (control) = Farmer's conventional fertilization with no Zn-fertilizer; $\mathrm{T} 2=\mathrm{T} 1+2 \mathrm{~kg}$ ha-1 $\mathrm{Zn}$-chelate; $\mathrm{T} 3=\mathrm{T} 2$ + applying $50 \mathrm{~kg} \mathrm{ha}^{-1}$ soluble sulfate potassium containing $\mathrm{Zn}$-chelate. The results illustrated that in control plots, while the yield was 23.3 tons per ha and the percentage of dry matter was 19.0 percent, the significant increase $(p<0.01)$ up to 34.0 tons per ha with 24 percent of dry matter was obtained in SSOP+Zn chelate treatment. Also there was a significant difference $(\mathrm{p}<0.01)$ between $\mathrm{Cd}$ concentration in control treatment and treatments in which $\mathrm{Zn}$-fertilizers have been used. The maximum Cd concentration has observed in control treatment with $0.13 \mathrm{mg} \mathrm{kg}^{-1}$ fresh weight and the minimum has obtained from SSOP+Zn chelate treatment by $0.01 \mathrm{mg} \mathrm{kg}^{-1}$ fresh weight. About Nitrate concentration in potato tubers of the field area, all data were located below the threshold concentration (60 mg kg ${ }^{-1}$ fresh weight). Therefore, for obtaining healthy agricultural products, using Zn-fertilizers in the agricultural soils with Zn deficiency should be considered seriously. By practicing balanced fertilization, i.e. applying $\mathrm{Zn}$-fertilizers especially by topdressing method, the quality and quantity of agricultural products as potato will be upgraded and the $\mathrm{Cd}$ and $\mathrm{NO}_{3}{ }^{-}$concentration will be decreased significantly, the country's quality of nutrition will improve and hence, the problem of malnutrition will be solved.
\end{abstract}




\section{Introduction}

Health comes from the farm [1]. One of the most important ways for any contaminant such as Cadmium (Cd) to enter the body of the consumer is through food. As the entry of any contaminant into the body in the long time can cause a variety of diseases, the need to use agricultural products with the lowest concentrations of contaminants is so serious; because agricultural products play the most vital role in the food basket of any society. Obviously, if the concentration of contaminants, especially nitrate $\left(\mathrm{NO}_{3}^{-}\right)$and $\mathrm{Cd}$ in these products is not under the threshold concentration, in the long period of time, will impose the society's health [2]. Using laboratory studies, the medical scientists determine the threshold concentration of each contaminant and then taking into account very strict considerations, they report the maximum concentration of any contaminant that does not harm human. This method also examines the use of a contaminant over a period of time and define its risk to the consumer. Cd is a non-essential heavy metal for human body that is absorbed through the food chain due to its chemical properties similar to some elements needed by the human body, containing Zinc and Iron [2]. Photosynthesis disorder, growth reduction, hypoglycemia and diseases such as nausea, vomiting, abdominal cramps, headache, hypertension, osteoporosis, pneumonia, renal failure, liver and heart disease are some of the effects of $\mathrm{Cd}$ on the human body [3]. The first adverse effect of $\mathrm{Cd}$ on the body is damage to the proximal renal cells that occurs at high concentrations of Cd [4]. Considering all the sources of $\mathrm{Cd}$ in soils, the main sources of Cd contamination in agricultural lands can be Phosphorus fertilizers (more than 100 million tons of phosphate fertilizers are consumed annually in the world), the use of sewage sludge and organic fertilizers [5]. It is necessary to mention that phosphate fertilizers have different concentrations of $\mathrm{Cd}$ from less than $1 \mathrm{mg} \mathrm{kg}^{-1}$ (ignored) to $450 \mathrm{mg} \mathrm{kg}^{-1}$ (high concentration) [4]. Livestock manures are more important in increasing the concentration of $\mathrm{Cd}$ in the soil compared to phosphate fertilizers due to the use of food additives, etc. Thus, the average annual consumption of phosphate fertilizers is $100 \mathrm{~kg} \mathrm{ha}^{-1}$ and livestock manure is 5 tons per hectare, which shows the high importance of livestock manures in increasing the concentration of $\mathrm{Cd}$ in the soil. According to the references, the global average soil $\mathrm{Cd}$ concentration is estimated in the range between 0.06 to 1.10 $\mathrm{mg} \mathrm{kg}^{-1}[6,7]$. However, abnormal levels of Cd (4 to $900 \mathrm{mg} \mathrm{kg}$ 1) have also been reported in countries such as Jamaica [8]. In the soils of Iran, the average concentration of $\mathrm{Cd}$ is reported to be 0.40 to $0.60 \mathrm{mg} \mathrm{kg}^{-1}$ [9] which this amount has also reached 2.50 to $3.60 \mathrm{mg} \mathrm{kg}^{-1}$ in some provinces such as Isfahan [10]. Cd can be involved in many physiological and biochemical processes of plants such as photosynthesis and nutrient uptake [11]. Application of Zinc-fertilizers leads to increased growth, decreased uptake and accumulation of $\mathrm{Cd}$. It changes the chemical forms of $\mathrm{Cd}$ and thus has an adverse effect on the accumulation of Cd in plants [12-15]. The use of nutrients such as Zinc-fertilizers will promote the yield and quality of crops as well as reduce the absorption of $\mathrm{Cd}[16,17]$. The interaction between $\mathrm{Zn}$ and $\mathrm{Cd}$ is so effective on Cd concentration in plants and also its bioavailability [18] and the available Cd content of the soil and as a result in the crops varies with the type of Phosphorus (P) fertilizers used and degree of its contamination with Cd [19]. Various factors are involved in the accumulation of Cd in plants, one of the most important factors is the plant species. As a study that examined the potential for Cd uptake by various plants, reported that among the plants, the highest accumulation of $\mathrm{Cd}$ is in leafy vegetables such as lettuce with $1.79 \%$ and the lowest is in trees with $0.10 \%$. Therefore, the use of plant species with less Cd accumulation compared to other species can be one of the ways to reduce Cd in the plant [20]. Accumulation of $\mathrm{Cd}$ in the plant can also be due to its interaction with other elements such as $\mathrm{Zn}$ and Iron. It should be noted that the arable soils of Iran are calcareous and the percentage of calcium carbonate equivalent in them in some cases reaches more than $50 \%$. This leads to increased Phosphorus deposition in the form of tri-calcium phosphate and encourages farmers to use imported phosphate fertilizers, which can be a source for more Cd to enter the soil. On the other hand, there is evidence of severe Zn deficiency in Iran's arable soils for several reasons, containing low amounts of organic matter and imbalanced fertilization [2]. On the other hand, a plant that has a high need for Zinc (Zn), to meet its needs, seeks available form of $\mathrm{Zn}$, but due to the lack of available $\mathrm{Zn}$ in arable soils, this plant is severely deficient, this element is encountered. Therefore, in order to meet its high $\mathrm{Zn}$ requirement, the plant supplies $\mathrm{Cd}$ due to its ionic similarity (ionic radius of 0.074 and $\mathrm{Cd}$ ionic radius of $0.09 \mathrm{~nm}$ ) through specific and even non-specific carriers (ZIP). It will be absorbed from the rhizosphere by the roots and accumulates in its seeds [17]. In other words, Cd and Zn have a similar status in terms of ionic shape and ionic structure. Thus, the correlation of these two elements to other elements such as sulfur, nitrogen and oxygen ligands is possible. Since $\mathrm{Zn}$ is an essential element and performs various processes such as protein synthesis, activation of enzymes and other roles in the plant, $\mathrm{Cd}$ cannot replace $\mathrm{Zn}$ in the metabolic activities of the plant. This is because Cd competes with $\mathrm{Zn}$ in the plant and disrupts metabolic processes $[2,21]$. Reported that under the conditions of using potassium sulfate containing $\mathrm{Zn}$-fertilizers, the accumulation of $\mathrm{Cd}$ in potato tubers has been reached less than the limit recommended by the CODEX. The maximum acceptable concentration of $\mathrm{Cd}$ in peeled potatoes according to the standard of the National Standard Organization of Iran and other international organizations is $0.10 \mathrm{mg} \mathrm{kg}^{-1}$ fresh weight of the plant. However, according to nutritionists in determining these standards, the maximum acceptable concentration is the condition of the plant that is consumed. For example, fresh potatoes are common in potatoes; therefore, these numbers mean the consumption of fresh potatoes, which is the same between international institutions and the Iran Standard Organization [22-25]. Due to the important role of Zinc in reducing the uptake of Cd in plants and the human body, therefore, Zn bio-fortification in farms can help to reduce the accumulation of $\mathrm{Cd}$ in plants and human body. Providing food for the growing population of the country and also the need for greater self-reliance in the production of strategic food products, is one of the main components of the country's independence. Potato (Solanum tuberosum L.) is a tuberous crop that plays an important role in 
feeding the people of the world and due to some of its characteristics, containing high production per unit in many European countries has replaced with wheat. Potatoes are the fourth largest food crop in the world after wheat, rice and corn, and are the second crop after corn in terms of number of producing countries [26]. Recent data show that potatoes produce $54 \%$ and $78 \%$ more protein per area unit than wheat and rice [26]. No other food, not even soy, can compete with potatoes in terms of energy production and nutritional value per area unit. It is estimated that one third of the population of tropical developing countries require the tubers and roots of potatoes as a food source [26]. In Iran, potatoes with a per capita consumption of about $43 \mathrm{~kg}$ per year (either fresh or processed) has an increasing value in the food basket of households and in addition to providing part of the daily calories and necessary vitamins of the people. In particular, vitamin $\mathrm{C}$ also has a decisive role and is effective on general health [27]. Due to various studies, the consumption of potatoes for people with type 2 diabetes should be controlled. Cd is found in many foods, but vegetables, especially tuberous vegetables such as potatoes, are by far the main source of $\mathrm{Cd}$ $[28,29]$. On the other hand, the food chain is one of the most important ways in which mineral contaminants can enter the human body [30]. Nitrate is a naturally occurring compound that is part of the nitrogen cycle, as well as an approved food additive. Higher levels of nitrate tend to be found in leaves whereas lower levels occur in seeds or tubers. Human exposure to nitrate is mainly exogenous through the consumption of vegetables, and to a lesser extent water and other foods [31]. Nitrate content in vegetables varies depending on the type of vegetables, genetic factor, level of nitrogen fertilization and soil nitrogen content [32]. The source of nitrate is mainly due to excessive use of nitrogen fertilizers (about 250 million tons of nitrogen fertilizers are used annually in the production of agricultural products) and also the lack of optimal use of fertilizers in the production of agricultural products. With excessive consumption of nitrogen fertilizers, nitrate is absorbed in large quantities by the plant, which reduces its regeneration in the roots due to high energy and sugar content. This ion transfers from roots to the leaves and It will be sent and accumulate there [33].

Due to the vital role of fertilizer application, fertilizer resource management is very important in terms of plant production. According to the Food and Agriculture Organization (FAO), at least $33 \%$ of the increase in agricultural production in the world over the past four decades has been due to the use of chemical fertilizers [34]. On the other hand, the results of 362 field experiments examined the role of chemical fertilizers on increasing the yield of some crops such as wheat, corn, soybeans and rice, concluded that 40 to $60 \%$ of agricultural production In the United States and the United Kingdom, is due to the use of chemical fertilizers which will be more than $60 \%$ in the tropics [35]. Increasing food demand by increasing population and reducing land resources in Iran will intensify agricultural activities through the use of irrigation, chemical fertilizers and pesticides in the future. Fertilizer application is expected to be double or even triple in the coming years, and the problem of contamination with mineral pollutants will increase [28]. At present, according to available documents, the area of rain fed and irrigated lands in the world is 1.5 billion hectares and in Iran is about 14 million hectares (18 million hectares in rainy years). On the other hand, the global consumption of macronutrient fertilizers based on nutrients per year is 176 million tons (nitrogen fertilizers 108, phosphate 40 and potassium 28 million tons). In other words, the average consumption of macro-nutrients based on nutrients, regardless of the level of irrigated and rain fed lands, is about 117 and in terms of fertilizer is approximately equal to $260 \mathrm{~kg}$ per hectare. Considering that the cultivation area of rain fed and irrigated lands in Iran is 14 million hectares, therefore, the annual need for macronutrients in the country in a growing year in terms of nutrient is 1.64 million tons and in terms of fertilizer amount is about 3.64 million tons. (Nitrogen fertilizers 2.50, phosphate 0.64 and potassium 0.50 million tons) are estimated in the ratio of 20-25-100 [36]. Therefore, considering the above information, now, $117 \mathrm{~kg} \mathrm{ha}^{-1}$ in terms of nutrients or $260 \mathrm{~kg} \mathrm{ha}^{-1}$ of fertilizer should be used annually in the country compared to the global consumption. This is while the application of macro nutrients in Iran is currently around two million tons per year ( $143 \mathrm{~kg}$ ha $\left.{ }^{1}\right)$. In other words, this figure is about $45 \%$ lower than the global average consumption and in addition, the ratio of fertilizer application in Iran is imbalanced. Currently, the accumulation of $\mathrm{Cd}$ in the countries agricultural lands and agricultural products has become an environmental and security problem. Increasing the concentration of $\mathrm{Cd}$ in the soil, enhances its uptake by the plant. Plants are the most important route of Cd transfer to the human food chain and it's accumulation in agricultural products causes toxicity and acute and chronic diseases. Nowadays, the concentration of this element has increased in Iran's arable soils due to excessive consumption of phosphate fertilizers and lack of potassium and $\mathrm{Zn}$-fertilizer's application [2]. Therefore, this experiment was conducted to investigate the role of balanced fertilization, especially the effect of $\mathrm{Zn}$-fertilizers on potato yield and healthy potato production. Because in this case, the necessary solutions such as the possibility of using elements like potassium and $\mathrm{Zn}$ that can minimize its absorption by creating competition with $\mathrm{Cd}$, can be tested.

\section{Method and materials}

This experiment was carried out in 2020 growing season, in one of the potato fields of Babolan village in Ardabil vicinity with geographical coordinates of 38 degrees and 20 minutes north and 48 degrees and 21 minutes east at an altitude of 1500 meters above sea level. According to 30-years meteorological statistics, the rainfall in this region is between $280-300 \mathrm{~mm}$, which is mostly winter rainfall.

In the first phase of the study, which was conducted with the aim of investigating and monitoring the Cd concentration in potato tubers produced by conventional fertilization method; potato samples were collected from 10 most favorable markets in the Ardabil province in the form of imbalanced completely randomized design to investigate the effect of farmer's conventional fertilization method on $\mathrm{Cd}$ concentration. Samples were transferred to the laboratory immediately after 
collecting and were dried to reduce the cd content error, since it's a volatile element. To assess the risks of $\mathrm{Cd}$, tuberous samples were examined in two forms, with and without peel. The thickness of the peel was the same in all samples, so in each tuber sample, a number of tubers without peel and some with peel were tested, and after marking, the tuber samples dried in the oven for a period of time. They were placed at $70^{\circ} \mathrm{C}$ for 72 hours. After drying the samples, the percentage of dry matter and moisture content of potato tubers were measured. After drying, the samples were crushed, passed through a 0.4 mesh sieve and powdered. The Cd concentration analysis in potato tubers using wet digestion method by nitric acid [37] performed by ICP (Inductively coupled plasma mass spectrometry) device. In the second phase of the study, which aimed to investigate the $\mathrm{Cd}$ concentration in potato tubers by using $\mathrm{Zn}$-fertilizers, soil sampling was performed in June 2020 from a depth of $0-30 \mathrm{~cm}$ of soil surface. After collecting the samples and air drying the soil, one sample weighing one kilogram was isolated and transferred to laboratory. Regarding the measurement of physical parameters, it was sufficient to measure the soil texture.

About chemical parameters, soil Nitrogen by Kjeldahl method, Organic Carbon by Walkley and Black method, soil Phosphorus by Olsen extractor method, soil available potassium by flame photometry method using Ammonium acetate [38], soil Bicarbonate, pH, EC and Finally, soil Cd, Zn and Iron concentration were analyzed by DTPA extraction [39] using atomic absorption spectroscopic device (Table 1).

The Cd, Zn, pH, EC and Bicarbonate in irrigation water also were analyzed after sampling (Table 2).

This experiment was performed in a randomized complete block design with 3 replications (blocks) and 3 treatments. Based on this, the total number of experimental plots was

Table 1: Some physical-chemical properties of the studied soil.

\begin{tabular}{|c|c|c|c|}
\hline Properties & amount & Properties & Amount \\
\hline Depth $(\mathrm{cm})$ & $0-30$ & Total Nitrogen $(\%)$ & 0.098 \\
\hline Soil texture & Loam & P avail. $\left(\mathrm{mg} \mathrm{kg}^{-1}\right)$ & 13 \\
\hline $\mathrm{pH}$ & 7.83 & $\mathrm{~K}$ avail. $\left(\mathrm{mg} \mathrm{kg}^{-1}\right)$ & 830 \\
\hline EC $\left(\mathrm{dS} \mathrm{m}^{-1}\right)$ & 3.66 & $\mathrm{Fe}\left(\mathrm{mg} \mathrm{kg}^{-1}\right)$ & 5.96 \\
\hline TDS $\left(\mathrm{mg} \mathrm{l}^{-1}\right)$ & 5925 & $\mathrm{Zn}\left(\mathrm{mg} \mathrm{kg}^{-1}\right)$ & 0.89 \\
\hline $\mathrm{OC}(\%)$ & 0.819 & $\mathrm{Cd}\left(\mathrm{mg} \mathrm{kg}^{-1}\right)$ & 0.5 \\
\hline $\mathrm{OM}(\%)$ & 1.411 & Total P $\left(\mathrm{mg} \mathrm{kg}^{-1}\right)$ & 594.5 \\
\hline $\mathrm{HCO}_{3}^{-}(\mathrm{meq} \mathrm{l}$ & & \\
\hline
\end{tabular}

Table 2: Some Chemical properties of the irrigation water.

\begin{tabular}{|c|c|}
\hline Properties & amount \\
\hline $\mathrm{pH}$ & 7.41 \\
\hline $\mathrm{EC}\left(\mathrm{dS} \mathrm{m}^{-1}\right)$ & 2.66 \\
\hline $\mathrm{TDS}\left(\mathrm{mg} \mathrm{l}^{-1}\right)$ & 1839 \\
\hline $\mathrm{HCO}_{3}^{-}\left(\mathrm{meq}^{-1}\right)$ & 4.46 \\
\hline $\mathrm{Zn}\left(\mathrm{meq} \mathrm{l}^{-1}\right)$ & 0.06 \\
\hline $\mathrm{Cd}\left(\mathrm{meq} \mathrm{l}^{-1}\right)$ & 0.008 \\
\hline
\end{tabular}

9 plots, each plot with an area of 30 square meters was considered as an experimental unit. In 2020 growing season the land was deeply plowed with the remaining organic crop residues (wheat) and the disk operation was performed based on the cultivation arrangement and the experimental design, then the cultivation was performed and the treatments were applied randomly in each experimental block. Tuberous seeds were selected from Agria variety and planted at a distance of 20 to $25 \mathrm{~cm}$ from each other. Irrigation was done in the form of strips, once a week according to the design of the irrigation system taking into account the slope of the land and for a period of approximately 10 hours with uniform coverage of the rows. After harvesting, In order to determine the yield, tubers of 10 square meters of each plot were selected. To measure the percentage of tuber's dry matter, 10 large, medium and small tubers, after washing with ordinary water and distilled water and then weighing, were cut into thin slices and placed in an oven at $65^{\circ} \mathrm{C}$ for 48 hours to dry completely. Then the dry weight of the samples was measured and the percentage of dry matter of the tubers was calculated [40], then the concentration of Phosphorus, $\mathrm{Zn}$ and $\mathrm{Cd}$ was analyzed in the tubers. Phosphorus, $\mathrm{Zn}$ and $\mathrm{Cd}$ analysis were done using dry ashing method [41]. Then the concentration of these elements was investigated using spectrophotometer [42] and ICP device respectively. The Cd concentration also analyzed using colorimetric determination of nitrate by nitration of Salicylic acid [43]. Statistical analysis of data were performed using SAS software and Duncan's multiple range test was used to compare the means at the level of $1 \%$.

\section{Results}

The results showed that the maximum concentration of Cd among the samples was $0.14 \mathrm{mg} \mathrm{kg}^{-1}$ fresh weight and the minimum was 0.02 . According to the results, no significant difference was observed between potato samples with and without peel $(\mathrm{p}>0.82)$. The threshold concentration for $\mathrm{Cd}$ in potato tubers, according to international organizations, is $0.1 \mathrm{mg} \mathrm{kg}^{-1}$ fresh weight, which can be converted into the permissible concentration of $\mathrm{Cd}$ in tubers based on dry weight, taking into account the percentage of dry matter in potatoes. The data show that the concentration of Cd in the potato tubers is defined less than critical level in all sampling points except two points. Of course, the range of data reminds us of the need to pay attention to plant nutritional management and to observe balanced and optimal fertilization in order to prevent the accumulation of Cd (Figure 1).

\section{Potato tubers yield}

According to Table 3, the effect of (SSOP+Zn chelate) and Zn chelate treatments on potato tubers yield was significant at the level of $1 \%(\mathrm{p}<0.01)$. The highest tuber yield was related to the (SSOP+Zn chelate) treatment by $\left(34000 \mathrm{~kg} \mathrm{ha}^{-1}\right)$ and the lowest in control (Zno) by (23300 $\mathrm{kg} \mathrm{ha}^{-1}$ ) (Figure 2 ).

\section{Potato tubers dry matter}

The results showed that at the level of $1 \%(p<0.01)$, there is a significant difference between the farmers conventional fertilization method and (SSOP $+\mathrm{Zn}$ chelate) treatment. 
However, there is no significant difference between $(\mathrm{SSOP}+\mathrm{Zn}$ chelate) treatment and the $\mathrm{Zn}$ chelate treatment at the level of $1 \%(\mathrm{p}<0.01)$ But, the dry matter percentage in $(\mathrm{SSOP}+\mathrm{Zn}$ chelate) treatment increased numerically. According to the results, in the condition of using ( $\mathrm{SSOP}+\mathrm{Zn}$ chelate), the highest percentage of dry matter $(24 \%)$ obtained and the lowest (19\%) was related to the condition without using $\mathrm{Zn}$ fertilizers (Table 4, Figure 3).

\section{Cd concentration in potato tubers}

It is obvious that, There is a significant difference $(\mathrm{p}<0.01)$ between Cd Concentration in control plot's potato tubers and treatments in which $\mathrm{Zn}$-fertilizers have been used. The Maximum Cd concentration has observed in Control treatment by $0.13 \mathrm{mg} \mathrm{kg}^{-1}$ fresh weight and the minimum has obtained from (SSOP+Zn chelate) treatment by $0.01 \mathrm{mg} \mathrm{kg}^{-1}$ fresh weight (Table 5, Figure 4).

\section{Zinc concentration in potato tubers}

The $\mathrm{Zn}$ analysis results also illustrates the Significant difference $(p<0.01)$ between treatments. It's obvious that the

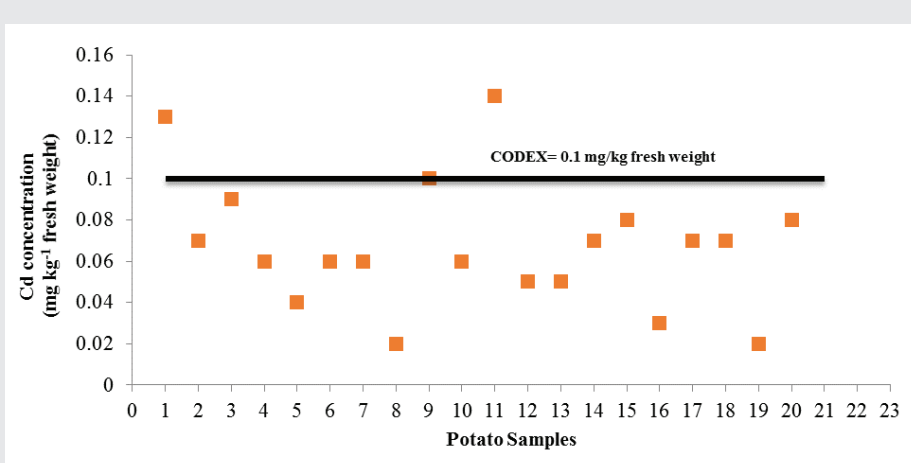

Figure 1: Cd concentration in potato tubers of Ardabil province.

Table 3: Effects of studied treatments on the tubers yield.

\begin{tabular}{|c|c|c|c|}
\hline Source of variation & df & Mean square & F \\
\hline R & 2 & 2111111.1 & $0.76^{\mathrm{ns}}$ \\
\hline Zn & 2 & 100777777.8 & $36.28^{\star \star}$ \\
\hline Error & 4 & 2777777.8 & - \\
\hline$* \star$ : (Significant at 1\%); *: (Significant at 5\%) and & ns: (Non-significant) \\
\hline
\end{tabular}

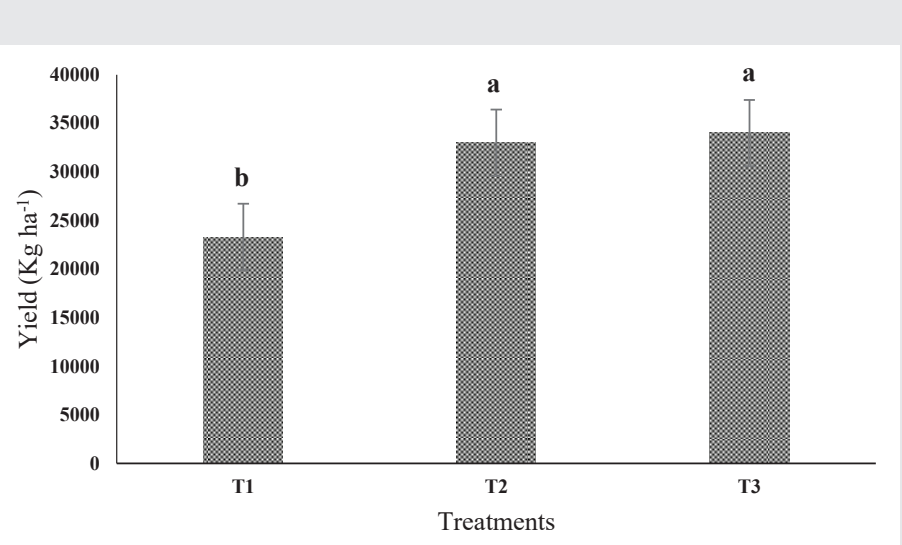

Figure 2: The significant effect of treatments on tubers yield $(p<0.01)$.
Table 4: Effects of studied treatments on the tubers Dry matter.

\begin{tabular}{|c|c|c|c|}
\hline Source of variation & df & Mean square & F \\
\hline R & 2 & 3.2394 & $1.94^{\text {ns }}$ \\
\hline Zn & 2 & 21.3445 & $12.76^{\star \star}$ \\
\hline Error & 4 & 1.6721 & - \\
\hline
\end{tabular}

**: (Significant at 1\%); *: (Significant at $5 \%$ ) and ns: (Non-significant)

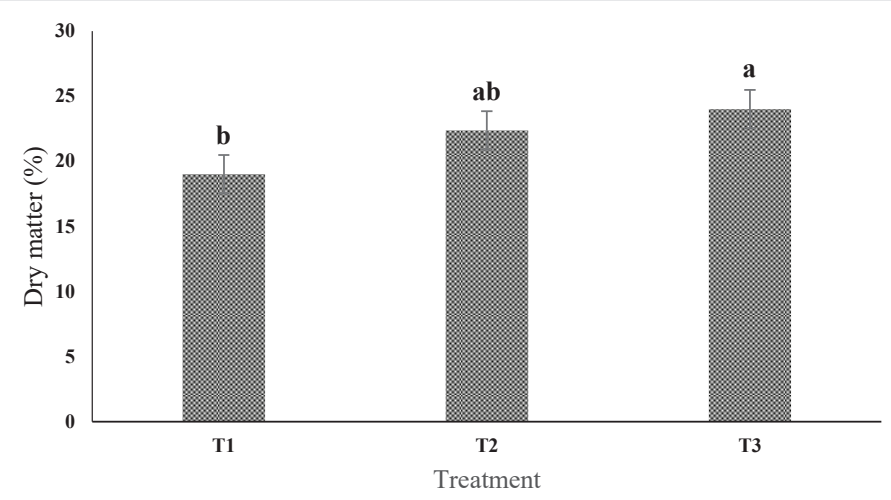

Figure 3: The significant effect of treatments on tubers Dry matter percentage $(p<0.01)$.

Table 5: Effects of studied treatments on the Cd concentration.

\begin{tabular}{|c|c|c|c|}
\hline Source of variation & df & Mean square & $\mathbf{F}$ \\
\hline R & 2 & 0.00103 & $8.86^{\text {ns }}$ \\
\hline Zn & 2 & 0.00973 & $83.43^{\star \star}$ \\
\hline Error & 4 & 0.0001166 & - \\
\hline **: (Significant at 1\%); *: (Significant at 5\%) and ${ }^{\text {ns: (Non-significant) }}$ \\
\hline
\end{tabular}

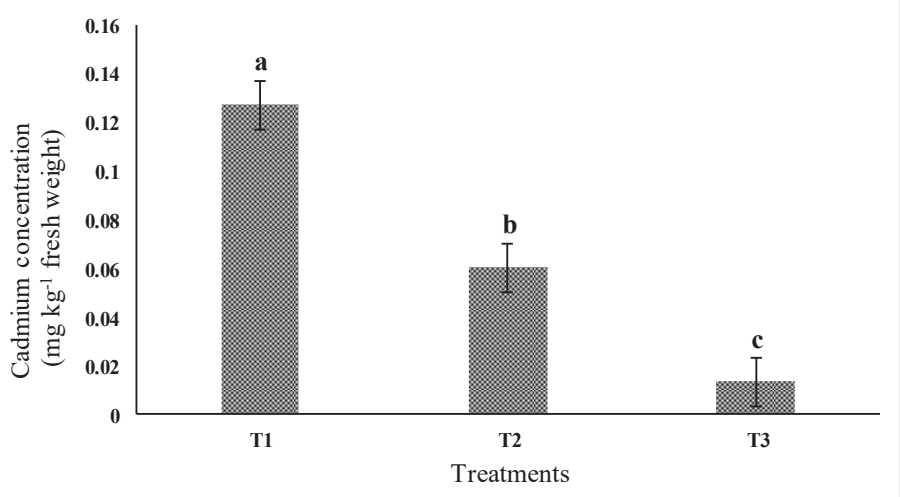

Figure 4: The significant effect of treatments on tubers Cd concentration $(p<0.01)$

$\mathrm{Zn}$ chelate treatment is at the head of the game by $40.5 \mathrm{mg} \mathrm{Zn}$ per kg dry weight, In contrast, the control treatment contains the least $\mathrm{Zn}$ concentration by $22.1 \mathrm{mg} \mathrm{kg}^{-1}$ dry weight (Table 6, Figure 5).

\section{Phosphorus concentration in potato tubers}

The Phosphorus analysis result also depicts the significant difference $(P<0.05)$ between treatments. It illustrates that the highest Phosphorus concentration was in control plot by 0.329 $\%$ whereas the $(\mathrm{SSOP}+\mathrm{Zn}$ chelate) treatment contained the lowest concentration by $0.196 \%$ (Table 7, Figure 6). 


\section{Nitrate concentration in potato tubers}

In order to evaluate the Nitrate concentration in potato tubers of the studied field, as one of the important and determining indicators in crop health, the nitrate concentration of tubers under treatments was studied and evaluated.

There is a significant difference in the level of $5 \%(\mathrm{P}<0.05)$ between the third treatment (SSOP $+\mathrm{Zn}$ chelate) and the second treatment (Zn chelate) (Table 8, Figure 7).

According to Figure 8, the range of nitrate concentration in potatoes varies from about $15.5 \mathrm{mg} \mathrm{kg}^{-1}$ fresh weight to 50.5 $\mathrm{mg} \mathrm{kg}^{-1}$ fresh weight, which is lower than the severe limit recommended by [44] is $60 \mathrm{mg} \mathrm{kg}^{-1}$ fresh weight. One of the reasons for the low nitrate concentration in this farm is the use of more organic fertilizers, which is also confirmed by the results of [45] research.

\section{Discussion}

Cd accumulation in food products often occurs in soils where phosphate fertilizers and sewage sludge containing high concentrations of $\mathrm{Cd}$ are used. The risk of Cd accumulation for the consumer in products containing $\mathrm{Cd}$ is a major concern that management strategies to reduce the accumulation of $\mathrm{Cd}$ in agricultural products are necessary. Therefore, this experiment

Table 6: Effects of studied treatments on the Zn concentration

\begin{tabular}{|c|c|c|c|}
\hline Source of variation & df & Mean square & F \\
\hline R & 2 & 13.390 & $5.90^{\text {ns }}$ \\
\hline Zn & 2 & 143.830 & $63.36^{\star \star}$ \\
\hline Error & 4 & 2.270 & - \\
\hline
\end{tabular}

**: (Significant at $1 \%) ; *$ : (Significant at $5 \%)$ and ${ }^{\text {ns: }}$ (Non-significant)

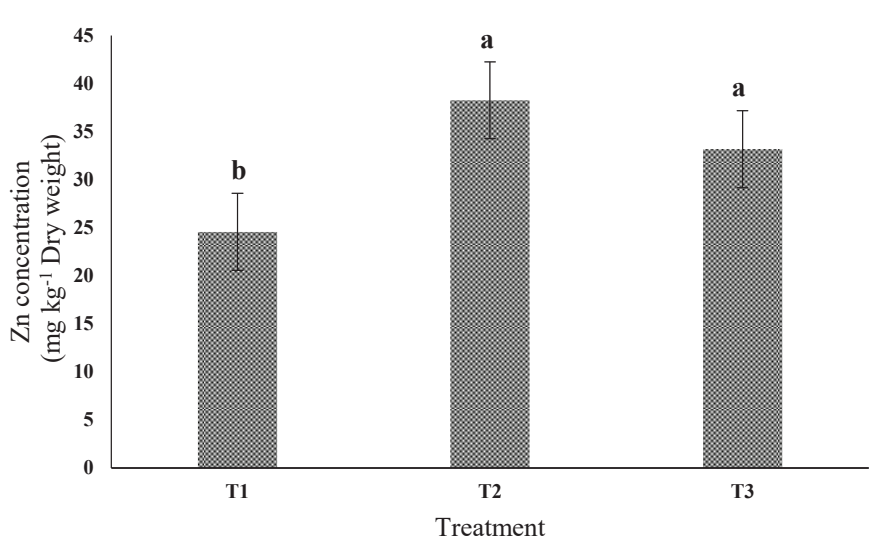

Figure 5: The significant effect of treatments on the $\mathrm{Zn}$ concentration $(p<0.01)$.

Table 7: Effects of studied treatments on the Phosphorus concentration.

\begin{tabular}{|c|c|c|c|}
\hline Source of variation & df & Mean square & F \\
\hline R & 2 & 0.003106 & $1.63^{\text {ns }}$ \\
\hline Zn & 2 & 0.01332 & $6.99 *$ \\
\hline Error & 4 & 0.001904 & - \\
\hline
\end{tabular}

**: (Significant at 1\%); *: (Significant at $5 \%$ ) and ${ }^{\mathrm{ns}}$ : (Non-significant)

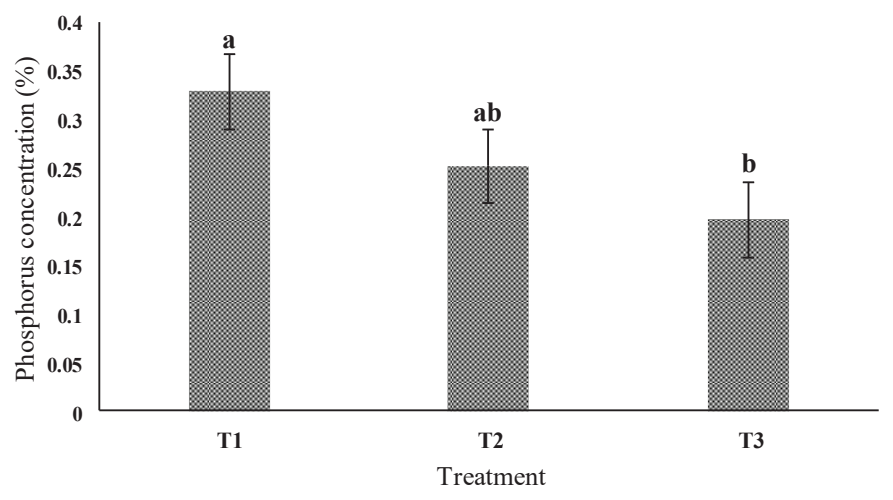

Figure 6: The significant effect of treatments on tubers Phosphorus concentration $(p<0.05)$.

Table 8: Effects of studied treatments on the Nitrate concentration.

\begin{tabular}{|c|c|c|c|}
\hline Source of variation & df & Mean square & F \\
\hline R & 2 & 176.14 & $4.94^{\text {ns }}$ \\
\hline Zn & 2 & 288.03 & $8.07^{\star}$ \\
\hline Error & 4 & 35.68 & - \\
\hline
\end{tabular}

**: (Significant at 1\%); *: (Significant at $5 \%$ ) and ${ }^{\mathrm{ns}}$ : (Non-significant)

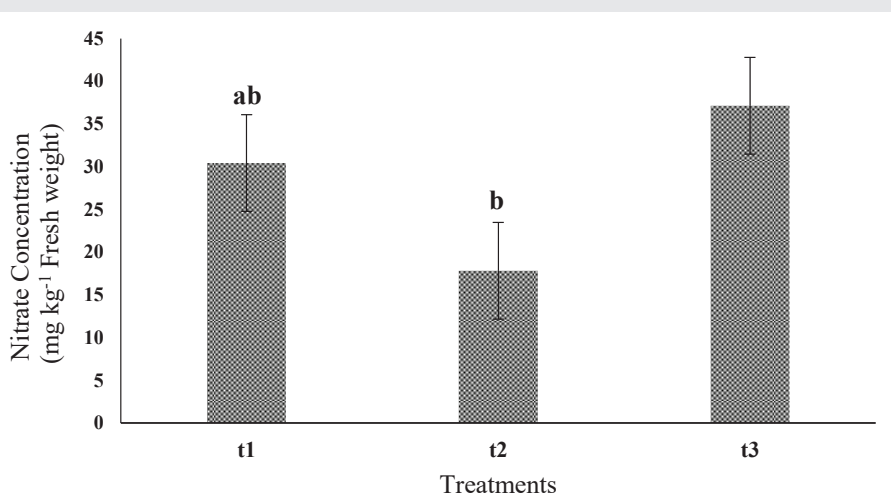

Figure 7: The significant effect of treatments on tubers Nitrate concentration $(p<0.05)$

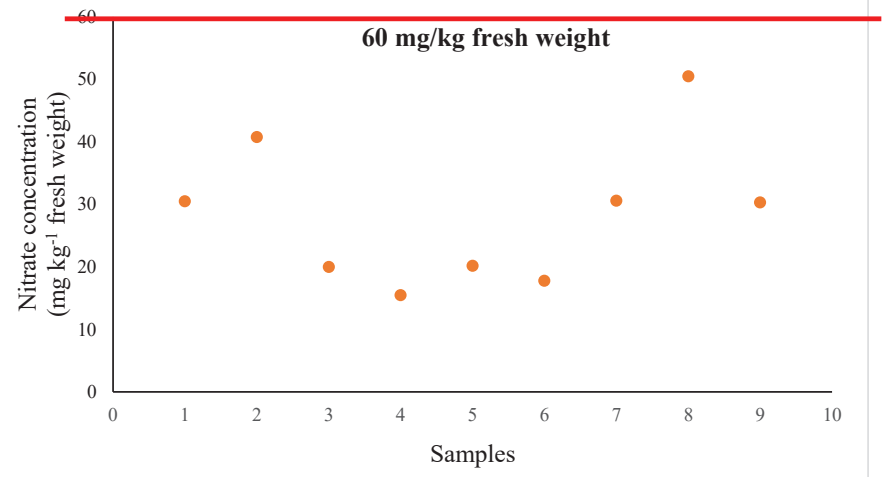

Figure 8: Nitrate concentration in field samples.

was performed with the aim of the investigating the effect of $\mathrm{Zn}$-fertilizers on $\mathrm{Cd}$ accumulation in potatoes.

The results showed that the tuber yield was affected by the studied treatments. The highest tuber yield $\left(34000 \mathrm{~kg} \mathrm{ha}^{-1}\right)$ 
was obtained in the (SSOP+Zn chelate) treatment which was $68 \%$ higher than the control. The most important reason for increasing the tubers yield due to consumption of $\mathrm{Zn}$ can be the role of this element in carbohydrate metabolism. Following its role in the structure of RNA polymerase enzymes and Carboxyl phosphate, this element increases the Glucose and starch content in the plant tissue and as a result will improve the yield. $\mathrm{Zn}$ is involved in the activity of enzymes in chlorophyll formation and consequently in photosynthesis and accelerates the formation of hormones such as tryptophan as the raw material of Auxins [46]. Potassium, in addition increases the carbohydrates as a result of photosynthesis and accelerates the transfer of soluble sugars made in the leaf (source) to the tuber (sink), which increases the starch in the tuber and subsequently improves tubers yield. It has also been reported that the efficiency of macro elements in plants depends on micro elements concentration. Therefore, among other reasons for increasing the yield of potato tubers in the presence of $\mathrm{Zn}$ fertilizers, the use of fertilizers according to the soil analysis results for increasing the efficiency of elements in the plant should be noticed [2]. The results of this study were consistent with the findings of other studies [47] also reported that the highest potato tubers yield was obtained from the combined treatment of potassium sulfate and $\mathrm{Zn}$ sulfate $[48,49]$. Also reported that the highest tuber yield and dry matter percentage of potato tubers were related to the combined treatment of sulfate, potassium sulfate and sulfuric acid [21]. Presented that the highest tuber yield and dry matter percentage relate to potassium sulfate containing $\mathrm{Zn}$ sulfate treatment which is so effective factor in improving potato inventory.

About the Cd concentration, Using Zn-fertilizers had significant effect on decreasing Cd concentration in potato tubers. [50] in their study in Australia reported that different levels of potassium sulfate and $\mathrm{Zn}$ sulfate significantly reduced the Cd concentration of potato tubers [51]. Reported that in soil contamination with $\mathrm{Cd}$, the presence of high amounts of potassium and $\mathrm{Zn}$ reduced the concentration of $\mathrm{Cd}$ in the leaves and fruits of tomatoes compared to the control. According to [2], Zn and Cd due to ionic similarity have a negative interaction in the soil during plant uptake, so that increasing the concentration of $\mathrm{Zn}$ in the soil reduces plant uptake of $\mathrm{Cd}$ due to $\mathrm{Zn}$ and $\mathrm{Cd}$ competition. The effect of potassium in reducing the concentration of Cd depends on its source (potassium sulfate or potassium chloride). It seems that increasing plant yield due to the use of potassium sulfate and the consequent dilution effect may be a possible reason for the positive effect of potassium sulfate in reducing $\mathrm{Cd}$ concentration $[17,21]$. Also reported in their study that root uptake and accumulation of $\mathrm{Cd}$ in the aerial parts of lettuce strongly depend on the concentration of $\mathrm{Zn}$ in the root area. Thus, with increasing $\mathrm{Zn}$ concentration compared to $\mathrm{Cd}$, the accumulation of $\mathrm{Cd}$ in the shoot decreased. They also reported that the interaction of $\mathrm{Zn}$ and $\mathrm{Cd}$ in plant uptake also depended on the time of $\mathrm{Zn}$ consumption. So that if $\mathrm{Zn}$ is consumed during plant growth, it has less effect on reducing $\mathrm{Cd}$ accumulation in shoots compared to conditions when $\mathrm{Zn}$ is consumed at the same time as planting. About the Zinc concentration, the highest zinc concentration was obtained in the second and third fertilizer treatments. One of the reasons for the numerical decrease in zinc concentration in the third treatment is the interaction between zinc and potassium at high concentrations. Because in the presence of potassium, zinc tends to be adsorbed by colloidal surfaces of soil particles due to its higher positive charge, and its adsorption by colloidal surfaces reduces its bioavailability in the plant. It is also possible that the concentration of phosphorus in the plant in the second and third treatments and also a significant decrease in the third treatment compared to the control treatment, as a result of the negative interaction between zinc and phosphorus in plant uptake has occurred.

\section{Conclusion}

Due to the serious need to reduce Cd contamination in agricultural products, it is recommended to reduce the concentration of $\mathrm{Cd}$ in the edible parts of plants through the use of $\mathrm{Zn}$-fertilizers. The results of this study showed that the use of $\mathrm{Zn}$-fertilizers significantly reduced the concentration of $\mathrm{Cd}$ in the potato tuber. So that the concentration of $\mathrm{Cd}$ in potato tubers in the treatment of $50 \mathrm{~kg} \mathrm{ha}^{-1} \mathrm{SSOP}+2 \mathrm{Kg} \mathrm{ha}^{-1} \mathrm{Zn}$ chelate decreased significantly $(\mathrm{p}<0.01)$ compared to the control. The effect of $\mathrm{Zn}$-fertilizers in reducing the concentration of $\mathrm{Cd}$ in potato tubers was such that the concentration of $\mathrm{Cd}$ in potatoes reached less than recommended by CODEX. The study of [52], with the aim of investigating the nitrate content in potato tubers showed that balanced consumption of macronutrients can significantly reduce the nitrate concentration in potato tubers. The study of [53], with the aim of investigating the amount of nitrate residue in potato tubers in major potato production areas of the country showed that nitrate concentration of $65 \%$ of potato samples harvested in Ardabil province was less than $200 \mathrm{mg} \mathrm{kg}^{-1}$ fresh weight, $23 \%$ of tubers nitrate concentration was 200 to $246 \mathrm{mg} \mathrm{kg}^{-1}$ fresh weight and $12 \%$ had high concentration of nitrate and were in the danger range. Therefore, it is recommended to observe the principles of balanced use of fertilizers, due to the amount of potassium and usable $\mathrm{Zn}$ in cultivated soils, since, we'll reduce the amount of $\mathrm{Cd}$ in agricultural products, In order to ensure food security and produce healthy crops.

\section{References}

1. Mayer JE, Wolfgang HP, Beyer P (2008) Biofortifield crops to alleviate micronutrient malnutrition. Curr Opin Plant Biol 11: 166-170. Link: https://bit.ly/3pqAV1J

2. Malakouti MJ (2018) The role of balanced fertilization on increasing yield and producing healthy agricultural products: Determining the amount, type and time of fertilization to achieve relative self-sufficiency, food security and increase farmer's incomes. $4^{\text {th }}$ publication. Farmer's house, 104, Mobaleghan publication, 458, Tehran. Iran. (In Persian).

3. Faustman E, Omenn G, Klassen C (2008) Em Casarett and Doull's Toxicology: The Basic Science of Poisons. CD Klaassen (Ed.)

4. Chaney RL, Ryan JA, Reeves PG (2013) Cd in Soils and its Transfer to Plants and the Human Food Chain Cell 301: 395-4852.

5. Alloway B, Steinnes E (1999) Anthropogenic additions of Cd to soils. In: Cd in soils and plants. McLaughlin, M. J., Singh, B. R. (Ed.). Springer, Boston, Landan 97-123. Link: https://bit.ly/3qXxNLk

6. Kaya C (2002) Effect of supplementary phosphorus on acid phosphatase 
enzyme activity and membrane permeability of zinc toxic tomato plants. $J$ Plant Nutr 25: 599-611. Link: https://bit.ly/3cflKos

7. Renildes LFF, Pereina MNJ, Neves CLJ (2014) Uptake and translocation of $\mathrm{Cd}$ and $\mathrm{Zn}$ in two lettuce cultivars. An Acad Bras Ciene 86: 907-923. Link: https://bit.ly/2M79kEq

8. Lasat MM, Pence NS, Garvin DF, Ebbs SD, Kochian LV (2000) Molcular physiology of Zinc transport in the zinc hyper accumulator Thlaspi caerulescens. J Exp Bot 51: 71-79. Link: https://bit.ly/3onDa4s

9. Pirzadeh M, Afyuni M, Khoshgoftarmanesh AH (2013) The status of Zinc and $\mathrm{Cd}$ in paddy soils in Isfahan, Fars and Khuzestan provinces and its effect on food security. Journal of Agricultural Science and Technology and Natural Resources. Soil \& Water sciences 60: 81-93.

10. Mottakan A, Kazemi A, Gili M, Ashorlou D (2009) Investigation of spatial distribution of $\mathrm{Cd}$ and determination of endangered vegetation in the central region of Iran located in Isfahan province using GIS and RS. Environmental Sciences 2: 65-76.

11. Rizwan M, Ali S, Abbas T, Zia-ur-Rehman M, Hannan F, et al. (2016) Cd minimization in wheat: a critical review. Ecotoxicol Environ Saf 130: 43-53. Link: https://bit.ly/3iQViCJ

12. Lin L, Zhou W, Dai H, Cao F, Zhang G, et al. (2012) Selenium reduces Cd uptake and mitigates $\mathrm{Cd}$ toxicity in rice. J Hazard Mater 235: 343-351. Link: https://bit.ly/3sXtOuV

13. Saidi I, Chtourou Y, Djebali W (2014) Selenium alleviates Cd toxicity by preventing oxidative stress in sunflower (Helianthus annuus) seedlings. $J$ Plant Physiol 171: 85-91. Link: https://bit.ly/39joKhw

14. Zhou H, Zhu W, Yang WT, Gu JF, Gao ZX, et al. (2019) Cd uptake, accumulation, and remobilization in iron plaque and rice tissues at different growth stages Ecotoxicol Environ Saf 152: 91-97. Link: https://bit.ly/3qTp24L

15. Rizwan M, Ali S, Ali B, Adrees M, Arshad M, et al. (2019) Zinc and iron oxide nanoparticles improved the plant growth and reduced the oxidative stress and Cd concentration in wheat. Chemosphere 214: 269-277. Link: https://bit.ly/2M81w5h

16. Yan $\mathrm{Y}$, Zhou YQ, Liang $\mathrm{CH}$ (2015) Evaluation of phosphate fertilizers for the immobilization of $\mathrm{Cd}$ in contaminated soils. PloS One 10: e0124022. Link: https://bit.ly/3pms2X1

17. Zare AA, Khoshgoftarmanesh $\mathrm{AH}$, Malakouti MJ, Bahrami HA, Chaney RL) 2018( Root uptake and shoot accumulation of Cd by lettuce at various Cd:Zn ratios in nutrient solution. Ecotoxicology and Environmental Safety J 148: 441 446. Link: https://bit.ly/2Ms7duC

18. Venkatachalam P, Jayaraj M, Manikandan R, Geetha N, Rene ER, et al. (2017) Zinc oxide nanoparticles (ZnONPs) alleviate heavy metal-induced toxicity in Leucaena leucocephala seedlings: a physiochemical analysis. Plant Physiol Biochem 110: 59-69. Link: https://bit.ly/3t34MPV

19. Rakocevic L, Pavolovic R, Duric M (2017) Effect of Phosphorus fertilizers on yield and Cd content of potato tuber. Acta Agriculturae Serbica 43: 37-46. Link: https://bit.ly/3po7cqj

20. Chaney RL, Ryan JA, Kukier U, Brown SL, Siebielec G, et al. (2000) Heavy Meta Aspects of Compost Use. In: Compost Utilization in Horticultural Cropping Systems. Stofella, P. J., Kahn, B. A., (Eds.). CRC Press, Boca Raton, FL.

21. Hosseini SA, Malakouti MJ, Shahabi A (2018) The effect of potassium sulfate and zinc sulfate on yield and Cd concentration in potato tubers. Journal of Soil Applied Research 4: 75-85.

22. Codex Alimentarius Commission (2005) Joint FAO/WHO Food Standards Programme. Fifth Session, Hague, Netherland 21-25 March 2011.

23. Codex Alimentarius (1995) Codex general standard for contaminants and toxins in food and feed, Codex Standard 193- 1995, adopted 1995, revised 1997, 2006, 2008, 2009, amended 2010, 2012. Rome (Italy): Codex Secretariat.
24. Australia and New Zealand Environmental and Conservation Council (1992) Australia and New Zealand Guidelines for the Assessment and Management of Contaminated Sites, Australia and New Zealand Environmental and Conservation Council and National Health and Medical Research Council, Canberra.

25. Commission E (2006) Commission Regulation (EC) No 1881/2006 of 19 December 2006 setting maximum levels for certain contaminants in foodstuffs. Off J Eur Union 364. Link: https://bit.ly/3okEhSz

26. Hosseini A (2015) The effect of potassium and zinc on the uptake and accumulation of $\mathrm{Cd}$ in potato tubers. M.Sc thesis, Soil science department, Faculty of Agriculture, Tarbiat Modares University, Tehran, Iran (In Persian).

27. Totiyayi A, Soleimani E (2009) On the reform of consumption pattern (11) "Reduction of waste of agricultural products". Office of Infrastructure Studies, Research Center of the Islamic Consultative Assembly of Iran. Serial number 27.

28. Jalali M (2008) Nitrate concentrations in some vegetables and soils in Hamadan, western Iran. Archives of Agronomy and Soil Science 54: 569-583. Link: https://bit.ly/2M6Aknv

29. Jalali M, Meyari A (2016) Accumulation of Heavy Metals in Potatoes Grown on Calcareous Soils of the Hamedan, Western Iran. Soil and Sediment Contamination: An International Journal 25: 365-377. Link: https://bit.ly/3cbk2o5

30. Pandey B, Suthar S, Singh V (2016) Accumulation and health risk of heavy metals in sugarcane irrigated with industrial effluent in some rural areas of Uttarakhand, India. Process Safety and Environmental Protection 102: 655666. Link: https://bit.ly/39lvHPd

31. Opinion of the Scientific Panel on Contaminants in the Food chain on a request from the European Commission to perform a scientific risk assessment on nitrate in vegetables, The EFSA Journal (2008) Journal number 689: 1-79.

32. Razgallah N, Chikh-Rouhou H, Boughattas I, M'hamdi M (2016) Nitrate contents some vegetable in Tunisia. Archives of Agronomy and Soil Sci 62 : 473-480. Link: https://bit.ly/3iMxekw

33. Malakouti MJ, Ladan SHh, Tabatabaee SJ (2013) Nitrate content in the edible parts of vegetables: Origin, safety, toxicity limits and the prevalence of cancer in Iran. 93-122 p. In: Sh. Umar, NA Anjum and NA Khan (Eds.). Nitrate in leafy vegetables: Toxicity and safety measures. IK International Publishing House Pvt. Ltd. New Delhi, India. 208.

34. Hamdallah G (2000) Soil fertility management: the need for new concepts in the region. In Proceedings of the FAO regional workshop on soil fertility management through farmer field schools in the near east, Amman 2-5.

35. Stewart WM, Dibb DW, Johnston AE, Smyth TJ (2005) The contribution of commercial fertilizer nutrients to food production. Agronomy Journal 97: 1-6. Link: https://bit.ly/3sXEZst

36. FAO (2013) Global land and water resources. Food and Agriculture Organization of United Nations. FAO Statistics. Link: https://bit.ly/2YkYHAp

37. Figueroa JAL, Wrobel K, Afton S, Caruso JA, Corona JFG, et al. (2008) Effect of some heavy metals and soil humic substances on the phytochelatin production in wild plants from silver mine areas of Guanajuato, Mexico. Chemosphere 70: 2084-2091. Link: https://bit.ly/3qXyPX

38. Margesin R, Schinner F (2005) Manual for soil analysis-monitoring and assessing soil bioremediation. Springer Science \& Business Media. Link: https://bit.ly/3iXp6xK

39. Lindsay WL, Norvell WA (1978) Development of a DTPA soil test for zinc, iron manganese, and copper. Soil Science Society of America Journal 42: 421-428. Link: https://bit.ly/3qTpOPd

Citation: Asbaghian Namini SK, Malakouti MJ, Ghavidel A (2021) The effect of Zinc chelate and Potassium sulfate topdressing on alleviating the Cadmium (Cd) and Nitrate $\left(\mathrm{NO}_{3}{ }^{-}\right)$toxicity in potato tubers of Ardabil province, Iran. J Agric Sc Food Technol 7(1): 034-042. DOI: https://dx.doi.org/10.17352/2455-815X.000085 
40. Khazaee HR, Arshadi MJ (2009) Effect of nitrogen topdress fertilizer application by using chlorophyll meter on yield and quality of potato (Agria cv.) in climate conditions of Mashhad. Journal of Horticulture Science 22: 49-63.

41. Miller RO (1998) High temperature Oxidation: Dry ashing. Taylor and Francis group. LLC.

42. Chapman HD, Pratt PF (1961) Methods of Analysis for soils, plants and waters. University of California. Division of Agricultural sciences. Link: https://bit.ly/3sZsfl9

43. Cataldo DA, Maroon M, Schrader LE, Youngs VL (1975) Rapid colorimetric determination of Nitrate in plant tissue by nitration of Salysilic acid. Communications in Soil Science and Plant Analysis 6: 71-80. Link: https://bit.ly/3onOyyY

44. Welch RM (2003) Farming for nutritious foods: Agricultural technologies for improved human health. IFA-FAO Agricultural Conference on Global Food Security and the Role of Sustainable Fertilization. Rome, Italy 1-24. Link: https://bit.ly/2NF6hnn

45. Haftbaradaran SH (2017) Effect of Plant Nutrition Management on Nitrate Concentration and Its Risk for Human Health in Isfahan Province. Ph. D. Dissertation. Tarbiat Modarres University, Tehran, Iran (In Persian).

46. Marschner H (1995) Mineral nutrition of higher plants. Second ed., Academic press. Harcourt Brace Company, Pub. Co. New York. 890. Link: https://bit.ly/3t0Fwdm

47. Malakouti MJ, Bybordi A, Tabatabaei SJ (2004) Balanced Fertilization of Vegetable Crops: An Approach to Enhance the Yield and Quality of Vegetables,
Reduce Contaminants and Improve Human Health. Ministry of Jihad-eAgiculture Press, Karaj, Iran, 338 (In Persian)

48. Malakouti MJ, Bybordi A (2006) Interaction between potassium (K) and zinc $(\mathrm{Zn})$ on the yield and quality of tuber vegetables. International Symposium on Balanced Fertilization for Sustainability of Crop Productivity. Ludhiana, India.

49. Dadkhah H (2012) The effect of different levels of zinc and boron on yield and dry matter in potato, MSc. Thesis. Tarbiat Modarres University, Tehran, Iran. (In Persian).

50. McLaughlin MJ, Maier N, Freeman AK, Tiller KG, Williams CMJ, et al. (1995) Effect of potassic and phosphatic fertilizer type, fertilizer Cd concentration and zinc rate on Cd uptake by potatoes. Fertilizer Research 40: 63-70. Link: https://bit.ly/2Mtgcfe

51. Ghasemi Z (2009) Studying the effect of potassium and zinc on the reduction of concentration of $\mathrm{Cd}$ pollutant in tomato plants (Lycopersicon esculentum L.) master's thesis, Payame Noor University of Najaf Abad, Esfahan, Iran. (In Persian).

52. Poberezny J, Wszelaczynska E, Wichorowska D, Jaskulski D (2015) Content of nitrates in potato tubers depending on the organic matter, soil fertilizer, cultivation simplifications applied and storage. Chilean Journal of Agricultural Research 75: 42-49. Link: https://bit.ly/3cgmfPc

53. Yeganeh M, Bazargan K (2016) Human health risks arising from nitrate in potatoes consumed in Iran and calculation nitrate critical value using risk assessment study. Human and Ecological Risk Assessment: An International Journal 22: 817-824. Link: https://bit.ly/3cesoLz
Discover a bigger Impact and Visibility of your article publication with Peertechz Publications

\section{Highlights}

* Signatory publisher of ORCID

* Signatory Publisher of DORA (San Francisco Declaration on Research Assessment)

* Articles archived in worlds' renowned service providers such as Portico, CNKI, AGRIS, TDNet, Base (Bielefeld University Library), CrossRef, Scilit, J-Gate etc.

* Journals indexed in ICMJE, SHERPA/ROMEO, Google Scholar etc.

* OAI-PMH (Open Archives Initiative Protocol for Metadata Harvesting)

* Dedicated Editorial Board for every journal

* Accurate and rapid peer-review process

* Increased citations of published articles through promotions

* Reduced timeline for article publication

Submit your articles and experience a new surge in publication services

(https://www.peertechz.com/submission).

Peertechz journals wishes everlasting success in your every endeavours.

Copyright: (C) 2021 Asbaghian Namini SK, et al. This is an open-access article distributed under the terms of the Creative Commons Attribution License, which permits unrestricted use, distribution, and reproduction in any medium, provided the original author and source are credited. 